\title{
Production of a complex coagulant from fly ash
}

\author{
Maohong Fan ${ }^{\mathrm{a}, *}$, Robert C. Brown ${ }^{\mathrm{a}}$, Thomas D. Wheelock ${ }^{\mathrm{b}}$, Adrienne T. Cooper ${ }^{\mathrm{c}}$, \\ Masakatsu Nomura ${ }^{\mathrm{d}}$, Yahui Zhuang ${ }^{\mathrm{e}}$ \\ ${ }^{a}$ Center for Sustainable Environmental Technologies, Iowa State University, Ames, IA 50011, USA \\ ${ }^{\mathrm{b}}$ Department of Chemical Engineering, Iowa State University, Ames, IA 50011, USA \\ ${ }^{c}$ Department of Civil and Environmental Engineering, University of South Carolina, Columbia, SC 29208, USA \\ d Department of Applied Chemistry, Osaka University, Suita, Osaka 565-0871, Japan \\ ${ }^{\mathrm{e}}$ Research Center for Eco-Environmental Sciences, Chinese Academy of Sciences, Beijing 100085, PR China
}

Received 16 December 2003; received in revised form 22 December 2004; accepted 23 December 2004

\begin{abstract}
Fly ash was explored as a raw material for the production of a complex coagulant containing ferric sulfate and aluminum sulfate. An analysis for five major metal oxides in $71 \mathrm{fly}$ ash samples collected from 32 power plants located in four different countries showed that the quantity of iron and aluminum oxides, in general, accounted for about $40 \%$ of the fly ash. A fly ash sample collected from City Power, Springfield, Illinois (CPSIL), was selected for more complete characterization by means of scanning electron microscopy (SEM) and other techniques. This fly ash was evaluated to determine the efficiency of converting the iron and aluminum components of the material into a complex coagulant when heated with sulfuric acid at different temperatures and reaction times. The maximum concentrations of $\mathrm{Fe}^{3+}$ and $\mathrm{Al}^{3+}$ in the complex coagulant prepared from the fly ash were obtained at $120^{\circ} \mathrm{C}$ and after $4 \mathrm{~h}$ of reaction time. These concentrations were $0.58 \mathrm{M} \mathrm{Fe}^{3+}$ and $0.93 \mathrm{M}$ $\mathrm{Al}^{3+}$, respectively. These concentrations correspond to conversion efficiencies of $84.8 \%$ for iron and $55.1 \%$ for aluminum in the fly ash. The complex coagulant proved to be an effective agent for reducing the turbidity, arsenic concentration and chemical oxygen demand (COD) of a given wastewater sample.
\end{abstract}

(C) 2005 Elsevier B.V. All rights reserved.

Keywords: Fly ash; Coagulation; Water treatment; Wastewater treatment

\section{Introduction}

Fly ash generally consists of fine spherical particles usually ranging in diameter from 0.5 to $100 \mu \mathrm{m}[1,2]$. Fly ash particles are inhomogeneous. The color of fly ash spans the spectrum from light tan to gray black. The physical properties of fly ash depend on the type of equipment used for collecting fly ash [3-6]. When coal is burned, the mineral matter forms ash mainly consisting of silicon, aluminum, iron and calcium compounds with lesser amounts of magnesium, sodium, potassium and titanium compounds. Typically, the constituents are reported in the form of compounds, which are mainly mixtures of sulfates, oxides

\footnotetext{
* Corresponding author. Tel.: +1 515294 3951; fax: +1 5152943091 .

E-mail address: fan@ameslab.gov (M. Fan).
}

and silicates. Most sulfates result from the interaction of pyrite and oxygen. Pyrite is the major source of iron oxide in coal ash. The silicates originate from the shale and clay minerals. The calcium and magnesium oxides are the products of decomposition of carbonate minerals. The chemical composition of fly ash is affected by the geological and geographical factors of the coal deposit, coal rank, boiler operation conditions, and fuel gas pollution control technology applied. Inorganic oxides constitute most of the fly ash. Furthermore, iron, aluminum and silicon are the major elements in fly ash while iron and aluminum are the major metallic ones. The typical concentrations of silicon, iron, aluminum, calcium, magnesium, sodium and potassium oxides in bituminous coals of the United States, are in the ranges of $20-60 \%, 5-35 \%, 10-35 \%, 1-20 \%, 0.3-4 \%$, $1-2 \%$ and $1-2 \%$, respectively [7]. The concentrations of 
alkali and alkaline earth oxides in sub-bituminous coals are generally higher that those in bituminous coals of the United States.

A large quantity of fly ash is generated in most of the regions of the United States each year. For example during 1999, about 3 million tons of fly ash were produced in Illinois, which is typically disposed of in landfills. Generally speaking, it costs \$30-50 for power plants to landfill each ton of fly ash emitted. Therefore, about $\$ 120$ million was spent on landfilling fly ash in Illinois.

Even though some fly ash is being used in various areas such as an admixture in concrete, higher valued products are desirable. As mentioned before, fly ash is rich in aluminum and iron oxides. Both compounds are the essential raw materials for the production of water and wastewater treatment coagulants [8-11]. Some countries in the world are so poor in bauxite and iron ore that they need to import these from other countries. For example the United States is buying bauxite from Guiana and Japan depends on Australia and other countries to meet its iron ore needs. The use of fly ash for the production of a complex coagulant makes it possible to utilize a waste material for water treatment. There is a promising potential market for complex coagulants produced from fly ash.

Production of a complex coagulant from fly ash is affected by different factors. This study focused on how these factors affect the efficiencies of converting iron and aluminum oxides in fly ash into $\mathrm{Fe}^{3+}$ or $\mathrm{Al}^{3+}$ in a complex coagulant consisting of ferric sulfate and aluminum sulfate. It also evaluated the effectiveness of the complex coagulant in water and wastewater treatment through the coagulating process.

\section{Experimental procedures}

\subsection{Characterization of fly ash}

\subsubsection{Scanning electron micrographs}

A Hitachi Model S-2460N scanning electron microscope (SEM) was used to analyze fly ash sample no. CPSIL at the Material Analysis and Research Laboratory at Iowa State University. The micrographs of the as-received fly ash sample no. CPSIL and ground fly ash sample no. CPSIL were prepared to demonstrate the change in regularity of the inorganic compounds in the fly ash.

\subsubsection{Analyses of major metals in fly ash}

The major metallic elements ( $\mathrm{Fe}, \mathrm{Al}, \mathrm{Ca}, \mathrm{Mg}, \mathrm{Na}$ and $\mathrm{K}$ ) in the collected $71 \mathrm{fly}$ ash samples were determined. Silicon, although one of major elements in fly ash, did not react with sulfuric acid under the given conditions in this research. Since it does not affect the production of the complex coagulant, it was not measured. All the chemicals used for the analyses were of analytical grade. The purpose of the analysis was to investigate the distribution of major metal oxides in fly ash and provide a basis for the calculation of the quantity of acid needed for the production of a complex coagulant.
In order to measure the concentrations of the major metallic elements in fly ash, each $1.0 \mathrm{~g}$ fly ash sample was mixed with $15.0 \mathrm{~mL}$ hydrochloric acid (Fisher Scientific, $37.5 \mathrm{wt} . \%$ ) and $10.0 \mathrm{~mL}$ deionized (DI) water, and boiled for $30 \mathrm{~min}$ to extract all of the five major metallic elements. The mixture resulting from the dissolving process was washed with $100 \mathrm{~mL}$ DI water and filtered. Then the filtrate was used for the measurement of the concentrations of $\mathrm{Fe}, \mathrm{Al}, \mathrm{Ca}, \mathrm{Mg}, \mathrm{Na}$ and K.

The iron concentration of the different fly ash samples was determined by the $\mathrm{SnCl}_{2}-\mathrm{TiCl}_{3}-\mathrm{K}_{2} \mathrm{Cr}_{2} \mathrm{O}_{7}$ method [12]. The fly ash extract was first acidified with hydrochloric acid and most of the $\mathrm{Fe}^{3+}$ in the solutions was reduced to $\mathrm{Fe}^{2+}$ by adding a prepared stannous chloride solution. The complete reduction of $\mathrm{Fe}^{3+}$ to $\mathrm{Fe}^{2+}$ was realized by the addition of a prepared titanous trichloride solution.

The concentration of aluminum in the fly ash was measured using the ethylenediaminetetracetic (EDTA) $-\mathrm{Na}_{2}-\mathrm{ZnCl}_{2}$ titration method [13]. The fly ash was first treated with a nitric acid solution. Then the EDTA- $\mathrm{Na}_{2}$ was added to chelate aluminum and other metal ions. Free EDTA was titrated with zinc chloride $\left(\mathrm{ZnCl}_{2}\right)$. A prepared potassium fluoride solution was used to free the chelated aluminum ions. Finally, the freed EDTA was again titrated with the prepared standard zinc chloride solution.

The concentrations of $\mathrm{Ca}, \mathrm{Mg}, \mathrm{Na}$ and $\mathrm{K}$ in a fly ash sample were measured by using a Thermo Finnigan Element Analyzer 1 ICP-MS at medium resolution, $m / \Delta m=4000$. The prepared diluted fly ash solutions were first nebulized at $100 \mu \mathrm{L} / \mathrm{min}$ with a PFA-100 Teflon nebulizer (Elemental Scientific). The metal elements were determined by using the standard, 'hot' plasma mode, with the plasma operating conditions selected to maximize the signals of the measured element in a standard solution. Because of background ions at $m / z=39, \mathrm{~K}^{+}$was determined by using a cool plasma, i.e., lower power and higher nebulizer gas flow rate. Each element produced a peak at the appropriate $\mathrm{m} / \mathrm{z}$ value. The concentration of each element was estimated based on the basis of the peak areas determined by external calibration with a standard solution. The following standard solution concentrations were employed: $50 \mathrm{ppb} \mathrm{Ca}, 2 \mathrm{ppb} \mathrm{Mg}, 50 \mathrm{ppb} \mathrm{Na}$ and $10 \mathrm{ppb}$ $\mathrm{K}$.

\subsection{Coagulation preparation and characterization}

\subsubsection{Pretreatment of fly ash sample}

Fly ash samples contain alkali and alkaline earth materials, confirmed by an analysis of the $71 \mathrm{fly}$ ash samples. These materials should be removed to reduce the consumption of sulfuric acid during the production of the sulfate-based, complex coagulants.

$\mathrm{CaO}, \mathrm{MgO}, \mathrm{K}_{2} \mathrm{O}$ and $\mathrm{Na}_{2} \mathrm{O}$ were removed by washing the sample with hot water. To wash the material, $500.0 \mathrm{~g}$ fly ash was added to $1000 \mathrm{~mL}$ water and the mixture was stirred and heated to $95^{\circ} \mathrm{C}$ for $1 \mathrm{~h}$. The resulting liquid extract was separated from the insoluble part of the fly ash sample by 
filtration. Then, another $1000 \mathrm{~mL}$ water was used to wash the water-insoluble part again at room temperature to completely remove all of the soluble alkaline metal oxides. Finally, the remaining insoluble material was dried at $115^{\circ} \mathrm{C}$ for $2 \mathrm{~h}$, and then weighed and used for the preparation of the sulfate-based complex coagulant. It is noted that water washing removed only part of the alkali and alkaline earth materials because part of the material was bound in alumino-silicate glasses.

\subsubsection{Preparation of complex coagulant}

The laboratory apparatus used to produce a complex coagulant in a liquid form from fly ash is illustrated schematically in Fig. 1. The preparation of the complex coagulant was carried out in a $500 \mathrm{~mL}$ stirred glass reactor [5] manufactured by ChemGLASS. Five inlets passed through the lid of the reactor. A Teflon shaft with an attached propeller was inserted through one inlet located in the center of the glass lid. The shaft was driven with a MULTI-CRAFT model Vaco65 variable speed motor [6]. A thermometer [7] was inserted through the second inlet for the purpose of monitoring the reaction temperature, which was controlled by a Neslab Model RTE111D refrigerated bath [3]. The third inlet was used to introduce water, sulfuric acid, and the fly ash sample into the reactor through a funnel [4]. Nitrogen was introduced through the fourth inlet before the reaction to improve the homogeneousness of the fly ash slurry. The nitrogen flow rate was controlled by a rotameter [2]. The last inlet was connected to a condenser [8], which was used to condense the water vapor from the reactor and return the condensate to the reactor. The condenser temperature was

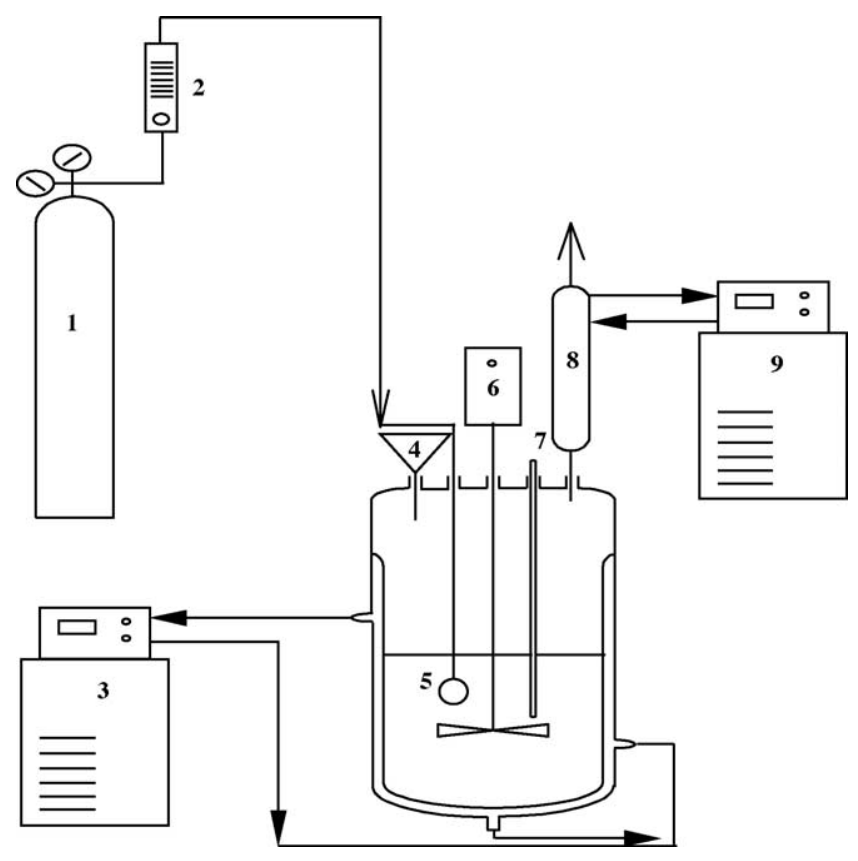

Fig. 1. Schematic illustration of reaction system used for producing complex coagulant from fly ash. (1) Nitrogen tank, (2) rotameter, (3) reactor heating unit, (4) funnel, (5) reactor, (6) stirrer motor, (7) thermometer, (8) condenser and (9) condenser-controlling unit. controlled with a CETAC TECHNOLOGIES Inc. Model 2050 condenser-regulating unit [9]. The bottom of the reactor was fitted with a product outlet as shown in Fig. 1.

Each run conducted for the preparation of the complex coagulant utilized $150 \mathrm{~g}$ fly ash no. CPSIL and $370 \mathrm{~mL}$ of $3.83 \mathrm{M}$ sulfuric acid solution. These amounts correspond to stoichiometric amounts required for the following chemical reactions:

$$
\begin{aligned}
& \mathrm{Fe}_{2} \mathrm{O}_{3}+3 \mathrm{H}_{2} \mathrm{SO}_{4} \rightarrow \mathrm{Fe}_{2}\left(\mathrm{SO}_{4}\right)_{3}+3 \mathrm{H}_{2} \mathrm{O} \\
& \mathrm{Al}_{2} \mathrm{O}_{3}+3 \mathrm{H}_{2} \mathrm{SO}_{4} \rightarrow \mathrm{Al}_{2}\left(\mathrm{SO}_{4}\right)_{3}+3 \mathrm{H}_{2} \mathrm{O}
\end{aligned}
$$

The first step of the operation was to open the lid of the reactor and add the prepared amount of sulfuric acid solution. Then the stirrer was started and operated at a speed of $180 \mathrm{rpm}$, followed by activating a Neslab Model RTE111D heating unit to control the reaction temperature specified for each test. Fly ash was added to the reactor when the temperature of the contents reached the required value. In this research, the sulfate-based complex coagulant was prepared at five different temperatures: $80,90,100,110$ and $120^{\circ} \mathrm{C}$. The reaction at each temperature was conducted for $4 \mathrm{~h}$. During the reaction, the color of the mixture in the reactor gradually changed to light red due to the dissolution of $\mathrm{Fe}^{3+}$ in the fly ash. The mixture was sampled with a $1 \mathrm{~mL}$ pipet at 30-min intervals after the reaction started to monitor the change in concentrations of $\mathrm{Fe}^{3+}$ and $\mathrm{Al}^{3+}$ ions. Each sampling took about $0.5 \mathrm{~mL}$ of the mixture, which was filtrated before use for analysis.

\subsubsection{Analysis of $\mathrm{Fe}^{3+}$ and $\mathrm{Al}^{3+}$ in the prepared sulfate- based complex coagulant. Analysis of $\mathrm{Fe}^{3+}$ and $\mathrm{Al}^{3+}$ in the prepared sulfate-based complex coagulant was completed with a Thermo Jarrel Ash-Iris Advantage Duo ICP-AES in- strument. The instrument was standardized for each element prior to its use by employing three different standard concen- trations and a blank. The corresponding standard concentra- tions for each element were $0,10,100$ and $200 \mathrm{ppm}$. A check standard was run before and after each sample set.}

\subsubsection{Measurement of contaminant elements in the com-} plex coagulant. An analysis of the complex coagulant produced at the highest reaction temperature $\left(120^{\circ} \mathrm{C}\right)$ and for the longest reaction time (240 $\mathrm{min}$ ), and having $0.58 \mathrm{M} \mathrm{Fe}^{3+}$ and $0.93 \mathrm{M} \mathrm{Al}^{3+}$, showed that the material had the concentrations of contaminants listed in Table 4.

\subsection{Coagulation performance of the produced sulfate-based coagulant}

\subsubsection{Preparations of coagulants and water samples}

Distilled water was added to the complex coagulant with concentrations of $0.58 \mathrm{M}$ iron and $0.93 \mathrm{M}$ aluminum in $100 \mathrm{~mL}$ beakers to prepare a $0.1 \mathrm{M}$ coagulant solution for jar tests. The concentration ratio of iron to aluminum in the diluted coagulant solution was equal to that in the original complex coagulant (0.58:0.93). 
Kaolin suspensions were prepared for testing the complex coagulant by dispersing kaolinite (Wilkinson Kaolin Assoc. Ltd., Gordon, GA, USA) in water mixtures composed of 50\% Ames City tap water with a turbidity of 0.4 NTU and $50 \%$ distilled water. The dissolved organic carbon (DOC) of Ames City tap water was less than $0.03 \mathrm{ppm}$. The mixing of Ames tap water with hardness level of $\sim 200 \mathrm{ppm}$ and distilled water was to lower the hardness level of the water for testing to a typical level of $\sim 100 \mathrm{ppm}$. The concentration of kaolinite in the prepared stock suspension was $5 \mathrm{~g} / \mathrm{L}$. $\mathrm{NaHCO}_{3}$ was used to regulate the alkalinity of tested water sample. The $\mathrm{pH}$ of the water samples was adjusted with either $0.1 \mathrm{M} \mathrm{HCl}$ or $0.1 \mathrm{M}$ $\mathrm{NaOH}$ solutions. Measurement of the turbidity of the water samples before and after coagulation was carried out with a Cole Parmer Model 8391-40 turbidity meter.

A stock arsenic solution was prepared from a reagentgrade sodium salt heptahydrate, $\mathrm{Na}_{2} \mathrm{HAsO}_{4} \cdot 7 \mathrm{H}_{2} \mathrm{O}$ (Matheson Coleman \& Bell). The concentration of $\operatorname{arsenic}(\mathrm{V})$ in the prepared stock solution was $1.0 \mathrm{~g} / \mathrm{L}$. The prepared $0.1 \mathrm{M}$ $\mathrm{HCl}$ or $0.1 \mathrm{M} \mathrm{NaOH}$ solutions were used to regulate the $\mathrm{pH}$ of arsenic water samples. Secondary solutions containing $100 \mathrm{mg} / \mathrm{L}$ arsenic were freshly prepared as needed by diluting the stock solution with deionized water. The concentration of arsenic in the water was determined with a HP4500 series ICP-MS.

A wastewater sample collected from Archer Daniels Midland (ADM), Clinton, Iowa, was used for chemical oxygen demand (COD) removal tests of a complex coagulant. The COD of sample was $1250 \mathrm{mg} / \mathrm{L}$ [14]. The COD of wastewater before and after treatment was measured using a standard analysis method [15].

\subsubsection{Jar tests}

Jar tests were performed using a Phipps \& Bird Model PB$700^{\mathrm{TM}}$ six-jar tester. The first step of the jar test was to fill each jar with $2000 \mathrm{~mL}$ of water. The water samples were stirred for $8 \mathrm{~min}$ at a speed of $100 \mathrm{rpm}$, in order to minimize the heterogeneity of the water sample and bring the water sample to equilibrium with the atmosphere. Then the required dosage of the complex coagulant solution was injected into the water sample. A rapid mixing of each water sample at $300 \mathrm{rpm}$ was conducted for a period of $2 \mathrm{~min}$, followed by $25 \mathrm{~min}$ of slow mixing at $30 \mathrm{rpm}$. After the completion of coagulation, the water samples were allowed to settle $30 \mathrm{~min}$. Finally, the supernatant was removed from the jar through the sampling tap to measure the residual turbidity, arsenic(V) or COD.

\section{Results and discussion}

Seventy-one fly ash samples were collected from 32 power plants located in four different countries (Australia, Canada, China and the United States) for preliminary characterization which involved determining the concentrations of the iron and aluminum oxides as well as the concentrations of the principal alkali and alkaline earth oxides. This was done

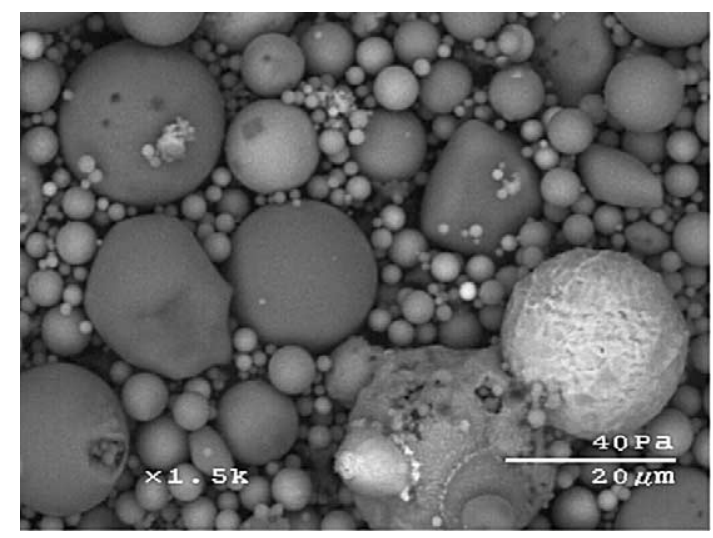

Fig. 2. SEM micrograph of as-received fly ash sample no. CPSIL.

to show that while the concentrations of the metal oxides varied widely from one source to another, many of the sources produced fly ash, which would be suitable for conversion into a coagulant for water and wastewater treatment. One of the fly ash samples (no. CPSIL) was selected for more complete characterization and for conversion into a complex coagulant by reaction with sulfuric acid. This sample was chosen because of its relatively high concentrations of iron and aluminum oxides and low concentrations of alkali and alkaline earth oxides. The resulting coagulant was subsequently tested to see how effective it was in reducing the turbidity of kaolin in water suspensions, and in reducing the concentration of arsenic in dilute solutions. It was further tested to determine its effectiveness in reducing the COD of a typical wastewater sample.

For each set of experimental conditions, every test was replicated three times. Therefore, each reported result represents an average of three determinations.

\subsection{Characterization of fly ash}

\subsubsection{Inorganic and organic matter in fly ash}

Micrographs of fly ash sample no. CPSIL before and after grinding are shown in Figs. 2 and 3, respectively. Fig. 2

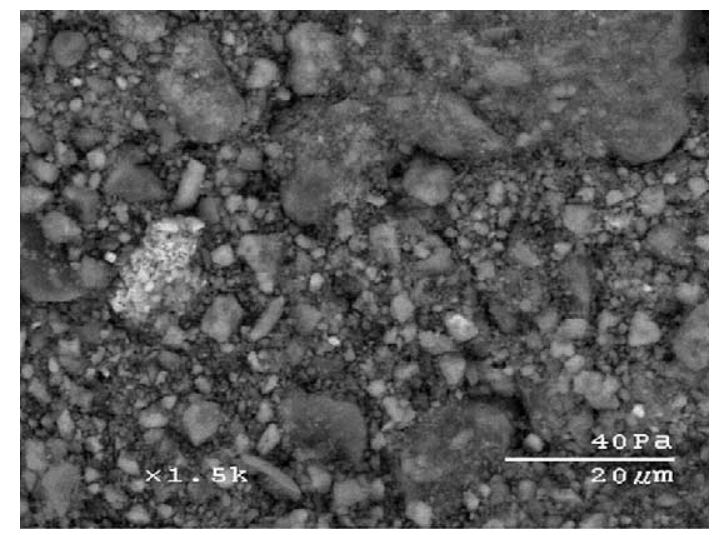

Fig. 3. SEM micrograph of ground fly ash sample no. CPSIL. 
Table 1

Composition of fly ash from different sources

\begin{tabular}{|c|c|c|c|c|c|c|c|}
\hline \multirow[t]{2}{*}{ Sample number } & \multirow[t]{2}{*}{ Sample source } & \multicolumn{6}{|c|}{ Element concentrations as oxides (wt.\%) } \\
\hline & & $\mathrm{Fe}_{2} \mathrm{O}_{3}$ & $\mathrm{Al}_{2} \mathrm{O}_{3}$ & $\mathrm{CaO}$ & $\mathrm{MgO}$ & $\mathrm{Na}_{2} \mathrm{O}$ & $\mathrm{K}_{2} \mathrm{O}$ \\
\hline GCA4 & Yaomeng/Pingdingshan, China & 8.2 & 21.0 & 4.5 & 6.5 & 2.3 & 1.6 \\
\hline GCA5 & Yaomeng/Pingdingshan, China & 8.9 & 20.2 & 5.6 & 7.8 & 0.8 & 2.0 \\
\hline GCA13 & Yaomeng/Pingdingshan, China & 7.9 & 19.8 & 5.9 & 6.9 & 1.4 & 0.3 \\
\hline GCA26 & Stanwell/Queensland, Australia & 15.3 & 30.2 & 6.4 & 3.6 & 2.0 & 0.2 \\
\hline GCA27 & Stanwell/Queensland, Australia & 14.7 & 28.9 & 6.5 & 3.0 & 1.3 & 0.7 \\
\hline 32AT & Scrubgrass/Kennerdell, PA & 9.2 & 26.4 & 15.1 & 1.9 & 0.2 & 1.2 \\
\hline AM36 & Titus Station/GPU Genco, PA & 7.3 & 25.8 & 5.5 & 2.5 & 1.4 & 1.5 \\
\hline AM37 & Sikeston Power Station, MO & 8.0 & 14.6 & 6.4 & 7.8 & 0.6 & 2.0 \\
\hline AM38 & Hennepin Station, IL & 9.1 & 24.6 & 16.1 & 4.2 & 0.3 & 0.5 \\
\hline AM39 & Streeter/Cedar Falls Utilities, IA & 10.2 & 23.8 & 8.9 & 5.2 & 2.1 & 1.4 \\
\hline AM40 & Pell-Electric Dept., IA & 11.3 & 25.8 & 11.2 & 3.8 & 0.4 & 0.8 \\
\hline AM41 & Pell-Electric Dept., IA & 10.9 & 24.2 & 10.9 & 4.2 & 1.1 & 0.8 \\
\hline AM43 & Fort Drum Cogeneration & 12.8 & 19.7 & 12.0 & 2.5 & 1.4 & 1.2 \\
\hline AM44 & Fort Drum Cogeneration & 13.2 & 18.5 & 11.2 & 3.3 & 2.0 & 1.2 \\
\hline AM45 & Fort Drum Cogeneration & 13.0 & 20.3 & 12.3 & 3.1 & 2.5 & 1.4 \\
\hline AM46 & Fort Drum Cogeneration & 13.4 & 20.2 & 10.4 & 2.9 & 2.4 & 0.9 \\
\hline AM47 & Fort Drum Cogeneration & 12.8 & 19.8 & 11.0 & 4.2 & 1.8 & 1.0 \\
\hline AM48 & Wisconsin Public Service, WI & 7.3 & 21.9 & 6.7 & 5.4 & 1.1 & 0.2 \\
\hline AM49 & Unit 1/Payette Power Plant, TX & 8.9 & 22.6 & 5.7 & 2.9 & 0.8 & 0.3 \\
\hline AM50 & Units 1 and 2/Chalk Point Units, MD & 10.2 & 27.5 & 5.2 & 6.1 & 2.3 & 1.2 \\
\hline AM51 & Texas-New Mexico Power, TX & 6.0 & 16.8 & 7.8 & 3.7 & 0.1 & 1.4 \\
\hline AM52 & Centralia Plant/Pacificorp, WA & 7.9 & 19.8 & 8.9 & 4.8 & 2.0 & 0.5 \\
\hline AM53 & Centralia Plant/Pacificorp & 10.6 & 25.9 & 12.9 & 3.2 & 0.8 & 2.0 \\
\hline AM55 & Dunkirk Steam Station, NY & 14.3 & 24.8 & 8.9 & 5.7 & 0.6 & 1.2 \\
\hline AM56 & Dunkirk Steam Station, NY & 14.2 & 25.0 & 8.9 & 3.8 & 1.3 & 1.0 \\
\hline AM57 & Dunkirk Steam Station, NY & 14.5 & 24.5 & 8.9 & 2.9 & 2.0 & 1.3 \\
\hline AM58 & Four Covners/Fruitland, NM & 12.4 & 23.2 & 12.3 & 2.1 & 1.6 & 0.4 \\
\hline AM59 & Dunkirk Steam Station, NY & 13.5 & 24.3 & 5.3 & 3.2 & 2.6 & 0.2 \\
\hline AM61 & Chamois Plant, MO & 8.2 & 18.0 & 8.8 & 4.0 & 2.1 & 1.4 \\
\hline AM62 & Brandon Gen. Station, Canada & 7.7 & 19.5 & 1.9 & 3.1 & 1.8 & 2.0 \\
\hline AM63 & Muscatine Power \& Water, IA & 9.8 & 20.2 & 12.1 & 3.2 & 3.0 & 0.5 \\
\hline AM64 & Elmer Smith Station, KY & 6.9 & 19.9 & 2.6 & 6.3 & 2.5 & 1.9 \\
\hline AM65 & Sundonce Plant, Canada & 6.7 & 12.9 & 8.5 & 2.9 & 2.4 & 1.1 \\
\hline AM66 & Sundonce Plant, Canada & 8.4 & 12.2 & 9.5 & 4.2 & 0.3 & 1.3 \\
\hline AM67 & Unknown & 19.7 & 32.5 & 15.9 & 7.1 & 1.9 & 2.0 \\
\hline AM68 & North Valmy Station, NV & 10.3 & 20.1 & 12.0 & 4.3 & 2.6 & 2.3 \\
\hline AM70 & UNC-CH Cogen. Facility, NC & 18.9 & 28.4 & 8.9 & 5.1 & 1.2 & 0.9 \\
\hline AM71 & UNC-CH Cogen. Facility, NC & 16.7 & 27.1 & 9.5 & 3.8 & 0.2 & 0.8 \\
\hline AM72 & J.H. Campbell Unit \#2, MI & 13.0 & 28.9 & 16.1 & 4.2 & 1.3 & 1.4 \\
\hline AM73 & J.H. Campbell Unit \#3, MI & 12.7 & 27.0 & 16.1 & 4.4 & 1.4 & 1.7 \\
\hline AM75 & St. Joseph Light Plant, MO & 11.8 & 19.3 & 7.8 & 5.2 & 1.2 & 0.1 \\
\hline AM77 & Lee Station/ Pelzer, SC & 17.5 & 26.1 & 9.2 & 2.8 & 0.3 & 1.2 \\
\hline AM78 & Pht. Scherer, GA & 20.9 & 34.9 & 8.7 & 5.2 & 0.6 & 1.4 \\
\hline 21839AT & Duquesne/Elrama 4B, PA & 15.3 & 26.4 & 10.9 & 4.3 & 1.9 & 1.3 \\
\hline $22001 \mathrm{AT}$ & Duquesne/Elrama 3B, PA & 12.9 & 24.6 & 13.4 & 4.0 & 2.5 & 0.7 \\
\hline $21825 \mathrm{AT}$ & Duquesne/Elrama 2A, PA & 11.0 & 21.3 & 8.3 & 4.8 & 1.8 & 1.6 \\
\hline $21832 \mathrm{AT}$ & Duquesne/Elrama 3B, PA & 17.6 & 23.2 & 12.7 & 5.0 & 2.4 & 0.7 \\
\hline 21837AT & Duquesne/Elrama 3B, PA & 16.8 & 24.0 & 13.8 & 4.1 & 2.6 & 1.1 \\
\hline 21846AT & Duquesne/Elrama 4B, PA & 15.9 & 27.6 & 11.4 & 3.9 & 1.8 & 1.5 \\
\hline 21960AT & Duquesne/Elrama 3B, PA & 14.3 & 24.9 & 12.9 & 5.3 & 2.0 & 0.4 \\
\hline 21964AT & Duquesne/Elrama 3B, PA & 18.2 & 23.4 & 13.5 & 3.7 & 2.6 & 1.3 \\
\hline 21996AT & Duquesne/Elrama 3B, PA & 16.4 & 23.6 & 13.6 & 4.0 & 2.2 & 0.8 \\
\hline 22368AT & Duquesne/Elrama 3B, PA & 17.0 & 23.8 & 13.8 & 4.2 & 1.8 & 1.0 \\
\hline 22288AT & Duquesne/Elrama 2A, PA & 10.8 & 21.9 & 7.2 & 4.5 & 1.2 & 1.9 \\
\hline 22343AT & Duquesne/Elrama 2A, PA & 9.7 & 19.3 & 8.9 & 3.8 & 1.5 & 2.2 \\
\hline $22462 \mathrm{AT}$ & Duquesne/Elrama 2A, PA & 11.1 & 19.8 & 8.0 & 4.9 & 1.2 & 1.7 \\
\hline $22473 \mathrm{AT}$ & Duquesne/Elrama 2A, PA & 10.2 & 19.7 & 6.3 & 4.4 & 1.3 & 1.8 \\
\hline 22499AT & Duquesne/Elrama 2A, PA & 11.9 & 21.2 & 6.9 & 4.6 & 1.6 & 2.0 \\
\hline 22332AT & Duquesne/Elrama 3B, PA & 17.7 & 23.9 & 13.6 & 4.7 & 2.7 & 1.9 \\
\hline 22336AT & Duquesne/Elrama 3B, PA & 17.9 & 23.4 & 13.2 & 5.2 & 2.0 & 1.5 \\
\hline 22339AT & Duquesne/Elrama 3B, PA & 13.2 & 24.4 & 13.0 & 3.4 & 1.9 & 1.3 \\
\hline
\end{tabular}


Table 1 (Continued)

\begin{tabular}{|c|c|c|c|c|c|c|c|}
\hline \multirow[t]{2}{*}{ Sample number } & \multirow[t]{2}{*}{ Sample source } & \multicolumn{6}{|c|}{ Element concentrations as oxides (wt.\%) } \\
\hline & & $\mathrm{Fe}_{2} \mathrm{O}_{3}$ & $\mathrm{Al}_{2} \mathrm{O}_{3}$ & $\mathrm{CaO}$ & $\mathrm{MgO}$ & $\mathrm{Na}_{2} \mathrm{O}$ & $\mathrm{K}_{2} \mathrm{O}$ \\
\hline 22342AT & Duquesne/Elrama 3B, PA & 12.8 & 24.3 & 12.2 & 3.6 & 1.8 & 2.0 \\
\hline $22345 \mathrm{AT}$ & Duquesne/Elrama 3B, PA & 13.5 & 23.3 & 14.5 & 4.1 & 2.2 & 1.6 \\
\hline 22348AT & Duquesne/Elrama 3B, PA & 13.9 & 22.9 & 13.5 & 2.9 & 1.7 & 1.9 \\
\hline 22352AT & Duquesne/Elrama 3B, PA & 12.9 & 23.8 & 12.9 & 4.7 & 1.7 & 2.0 \\
\hline 22356AT & Duquesne/Elrama 3B, PA & 13.4 & 24.1 & 12.8 & 3.9 & 2.0 & 1.5 \\
\hline 22360AT & Duquesne/Elrama 3B, PA & 13.1 & 23.3 & 12.5 & 4.0 & 2.4 & 1.6 \\
\hline 22368AT & Duquesne/Elrama 3B, PA & 13.8 & 24.4 & 11.7 & 4.3 & 2.2 & 1.0 \\
\hline 22372AT & Duquesne/Elrama 3B, PA & 13.0 & 23.3 & 13.6 & 4.4 & 1.8 & 1.8 \\
\hline 22518AT & Duquesne/Elrama 3B, PA & 12.9 & 24.6 & 12.9 & 4.5 & 2.4 & 1.7 \\
\hline CPSIL & City Power, Springfield, IL & 15.6 & 22.9 & 1.2 & 0.9 & 0.4 & 1.5 \\
\hline Range & 71 samples & $6.0-20.9$ & $12.2-34.9$ & $1.2-16.1$ & $0.9-7.8$ & $0.1-3.0$ & $0.1-2.3$ \\
\hline Average & 71 samples & 12.5 & 23.1 & 10.1 & 4.2 & 1.6 & 1.3 \\
\hline
\end{tabular}

shows that the inorganic material in the as-received fly ash was smooth, spherical and glassy, whereas the organic material was irregular, fragmented and porous. Compared with Fig. 2, Fig. 3 indicates that the particle size of the ground fly ash sample was reduced, and the spherical shape of the inorganic particles was partially destroyed.

\subsubsection{Distribution of major metal oxides in fly ashes}

The resulting analysis of a large number of fly ash samples is reported in Table 1. The results are reported in terms of the basic metal oxides even though other oxide forms, such as mullite $\left(\mathrm{Al}_{6} \mathrm{Si}_{2} \mathrm{O}_{13}\right)$, magnetite $\left(\mathrm{Fe}_{3} \mathrm{O}_{4}\right)$ and hematite $(\alpha$ $\mathrm{Fe}_{2} \mathrm{O}_{3}$ ) were also present $[5,6]$. The values were determined by using a combination of wet chemistry and instrumental analysis with the Thermo Finnigan Element 1 ICP-MS instrument. The experimental measurements showed that the distribution of the five major metal species in fly ash varies from one sample to another depending on the source of coal, burning process and method used for collecting fly ash. Table 1 also shows that the iron and aluminum oxides account for the major part of the metal oxide content of fly ash. Most of samples evaluated in this project contained from 30 to $40 \%$ iron and aluminum oxides. Among these samples, the concentrations of iron and aluminum are not less than 7.7 and $11.0 \%$, respectively. A typical liquid iron-aluminum sulfates complex coagulant contains $1.5 \%$ iron and $3.0 \%$ aluminum. Therefore, 1 ton of most fly ashes listed in Table 1 could be used theoretically to produce at least 3.5 tons of a liquid complex coagulant. Several fly ash samples in Table 1 contained very high concentrations of iron and aluminum compounds. For example the concentrations of iron and aluminum oxides in fly ash no. AM78 were 20.9 and $34.9 \%$, respectively, corresponding to $14.6 \%$ iron and $18.5 \%$ aluminum. Theoretically, more than 6 tons of a liquid sulfate-based complex coagulant could be produced from this fly ash sample.

The concentrations of calcium, magnesium, potassium and sodium oxides were generally not higher than 12, 5, 3 and $2 \%$, respectively. Solutions of these compounds have a wide range of applications in pollution control. For example such solutions can be used for acidic gas removal from fuel gas
Table 2

Concentrations of $\mathrm{Fe}^{3+}\left(C_{\mathrm{Fe}^{3+}}, \mathrm{M}\right)$ in the complex coagulant produced under different reaction conditions

\begin{tabular}{clllll}
\hline Reaction time (min) & $80^{\circ} \mathrm{C}$ & $90^{\circ} \mathrm{C}$ & $100^{\circ} \mathrm{C}$ & $110^{\circ} \mathrm{C}$ & $120^{\circ} \mathrm{C}$ \\
\hline 0 & 0 & 0 & 0 & 0 & 0 \\
30 & 0.0120 & 0.0315 & 0.0548 & 0.1008 & 0.1451 \\
60 & 0.0289 & 0.0767 & 0.1120 & 0.1838 & 0.2430 \\
90 & 0.0467 & 0.0912 & 0.1244 & 0.2427 & 0.3281 \\
120 & 0.0621 & 0.1222 & 0.2215 & 0.3090 & 0.3871 \\
150 & 0.0711 & 0.1493 & 0.2662 & 0.3648 & 0.4666 \\
180 & 0.0790 & 0.1947 & 0.3149 & 0.4338 & 0.4840 \\
210 & 0.0853 & 0.2024 & 0.3437 & 0.4936 & 0.5553 \\
240 & 0.0909 & 0.2681 & 0.3961 & 0.5156 & 0.5790 \\
\hline
\end{tabular}

produced by coal-fired power plants. Such solutions can also serve to neutralize low-pH wastewater before being treated by physicochemical and biological processes.

\subsection{Factors affecting the production of a complex coagulant}

\subsubsection{Effect of reaction temperature and time on the production of a complex coagulant}

The concentrations of $\mathrm{Fe}^{3+}$ and $\mathrm{Al}^{3+}$ in the prepared complex coagulant and corresponding conversion efficiencies for iron and aluminum oxides in the fly ash are indicated in Tables 2 and 3 and Figs. 4 and 5, respectively. The conversion

Table 3

Concentrations of $\mathrm{Al}^{3+}\left(C_{\mathrm{Al}^{3+}}, \mathrm{M}\right)$ in the complex coagulant produced under different reaction conditions

\begin{tabular}{clllll}
\hline Reaction time $(\mathrm{min})$ & $80^{\circ} \mathrm{C}$ & $90^{\circ} \mathrm{C}$ & $100^{\circ} \mathrm{C}$ & $110^{\circ} \mathrm{C}$ & $120^{\circ} \mathrm{C}$ \\
\hline 0 & 0 & 0 & 0 & 0 & 0 \\
30 & 0.0076 & 0.0252 & 0.0576 & 0.1367 & 0.2292 \\
60 & 0.0185 & 0.0613 & 0.1191 & 0.2415 & 0.3842 \\
90 & 0.0306 & 0.0734 & 0.1552 & 0.3191 & 0.5422 \\
120 & 0.0406 & 0.0995 & 0.2366 & 0.4132 & 0.6338 \\
150 & 0.0454 & 0.1207 & 0.2839 & 0.4964 & 0.7458 \\
180 & 0.0501 & 0.1600 & 0.3376 & 0.5806 & 0.7931 \\
210 & 0.0558 & 0.1756 & 0.3780 & 0.6475 & 0.8689 \\
240 & 0.0588 & 0.2123 & 0.4255 & 0.6882 & 0.9256 \\
\hline
\end{tabular}




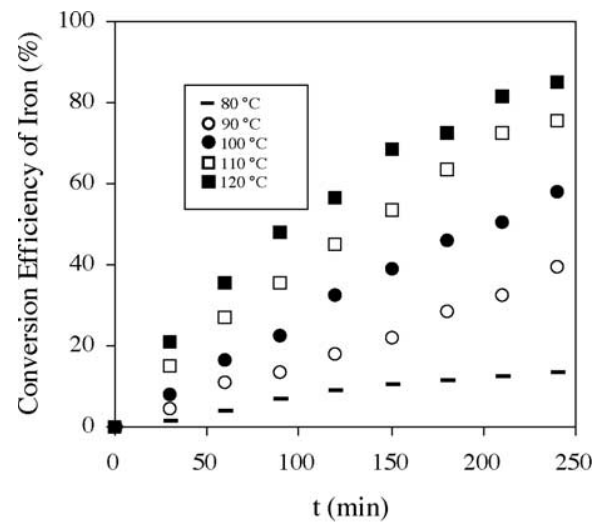

Fig. 4. Effect of reaction temperature and time on the conversion efficiency of $\mathrm{Fe}^{3+}$.

efficiency for iron is defined as the ratio of the mass of $\mathrm{Fe}^{3+}$ in the product to the mass of iron in the fly ash. The same definition applies to the conversion efficiency for aluminum. Tables 2 and 3 show that the concentrations of $\mathrm{Fe}^{3+}$ and $\mathrm{Al}^{3+}$ in the prepared complex coagulant increase with an increase in either reaction temperature or time. A similar trend is shown in Figs. 4 and 5 for the conversion efficiency. The effect of reaction temperature on the conversion of iron and aluminum oxides in a specific time is in agreement with reaction rate theory, which holds that the rate of a chemical reaction increases with temperature $[16,17]$. Furthermore, temperature has a larger effect on the rate of reaction of aluminum oxide with sulfuric acid than the rate of reaction of iron oxide with sulfuric acid, because it can be seen in Tables 2 and 3 that the concentration of $\mathrm{Al}^{3+}$ increases at a higher rate with temperature than does the concentration of $\mathrm{Fe}^{3+}$. Tables 2 and 3 show that after $240 \mathrm{~min}$ of reaction at $120^{\circ} \mathrm{C}$, the concentrations of $\mathrm{Fe}^{3+}$ and $\mathrm{Al}^{3+}$ in the complex coagulants reach values of 0.58 and $0.93 \mathrm{M}$, respectively. The corresponding conversion efficiencies of iron and aluminum (oxides) are 84.8 and $55.1 \%$, respectively. The lower conversion efficiency of aluminum (oxide) in fly ash may have resulted from the formation of an unfavorable structure of aluminum oxides during high-temperature coal combustion

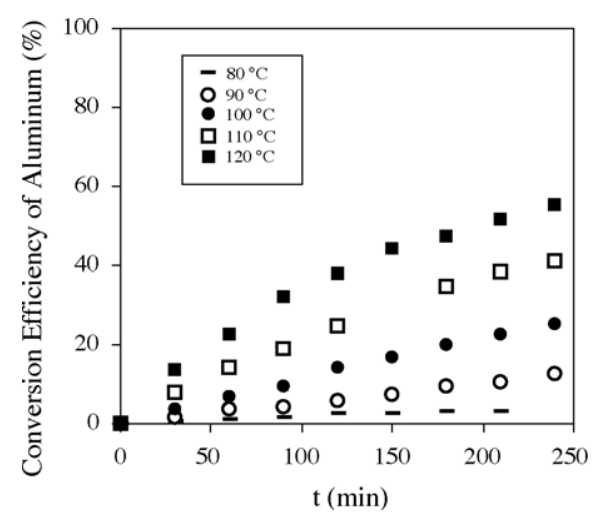

Fig. 5. Effect of reaction temperature and time on the conversion efficiency of $\mathrm{Al}^{3+}$.
Table 4

Concentrations of contaminant elements of the complex coagulant with $C_{\mathrm{Fe}^{3+}}=0.53 \mathrm{M}$ and $C_{\mathrm{Al}^{3+}}=0.98 \mathrm{M}$

\begin{tabular}{lc}
\hline Contaminant elements & Concentration $(\mathrm{ppm})$ \\
\hline $\mathrm{As}$ & 4.3 \\
$\mathrm{Ba}$ & 0.5 \\
$\mathrm{Cd}$ & 0.0 \\
$\mathrm{Cr}$ & 5.2 \\
$\mathrm{Cu}$ & 1.7 \\
$\mathrm{Hg}$ & 0.0 \\
$\mathrm{~Pb}$ & 13.5 \\
$\mathrm{Ni}$ & 2.3 \\
$\mathrm{Se}$ & 0.0 \\
$\mathrm{Ti}$ & 3.7 \\
\hline
\end{tabular}

[18]. The concentrations of $\mathrm{Fe}^{3+}$ and $\mathrm{Al}^{3+}$ in the sulfate-based complex coagulant or the conversion efficiencies of iron and aluminum oxides would probably have been higher if the reaction temperature had been increased further; however, it was not possible to investigate that possibility with the present system.

\subsection{Assessment of health risk of the complex coagulant}

The concentrations of different contaminant elements in the complex coagulant with $0.58 \mathrm{M} \mathrm{Fe}^{3+}$ and $0.93 \mathrm{M} \mathrm{Al}^{3+}$ are listed in Table 4. Typically, the coagulant dosage needed for water and wastewater treatment is less than 100 and $200 \mathrm{ppm}$, respectively. This indicates that the levels of $\mathrm{As}, \mathrm{Ba}, \mathrm{Cr}, \mathrm{Cu}$, $\mathrm{Ni}$ and $\mathrm{Ti}$ in water and wastewater could increase potentially by less than or about $1 \mathrm{ppb}$, but those of $\mathrm{Cd}, \mathrm{Hg}$ and Se would probably not change at the beginning of coagulation when the complex coagulant is used for water or wastewater treatment. The level of $\mathrm{Pb}$ in water and wastewater may increase by 1.3 and $2.6 \mathrm{ppb}$, respectively, during the initial stage of coagulation. The levels of $\mathrm{Cd}, \mathrm{Hg}$ and $\mathrm{Se}$ in water and wastewater should not be affected by adding the complex coagulant. Compared with current quality of water and wastewater and standards for drinking water and wastewater, the effect of the complex coagulant on the initial contaminant level would not be significant. Moreover, the complex coagulant itself is a good agent for removing the contaminant elements in the later phase of the coagulation process. Therefore, it is anticipated that the complex coagulant would not result in an additional health risk when applied to water or wastewater. However, this conclusion does not apply to the complex coagulants producing any fly ash. Each fly ash needs to be evaluated separately to determine the concentrations of possible contaminants before it is used for producing a coagulant.

\subsection{Performance of a complex coagulant in coagulation}

The performance of the complex coagulant was determined by conducting jar tests using water samples, which contained either suspended kaolin particles or a dissolved 


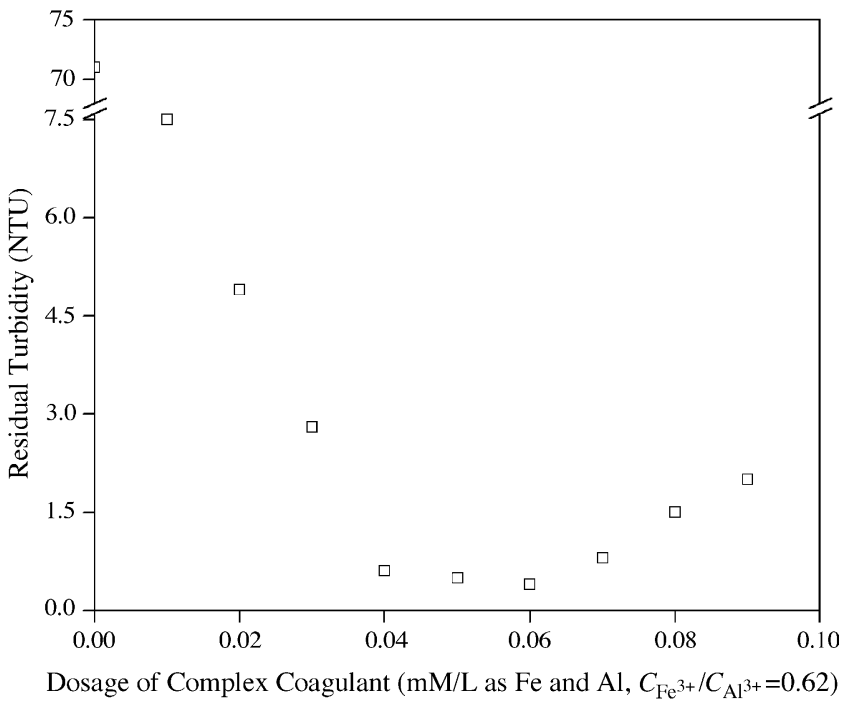

Fig. 6. Evaluation of complex coagulant produced from fly ash for removing turbidity of kaolinite suspensions (initial turbidity $=95 \mathrm{NTU}$, initial alkalinity as $\left.\mathrm{CaCO}_{3}=37 \mathrm{mg} / \mathrm{L} ; \mathrm{pH} 7.4\right)$.

arsenic compound. Other jar tests were conducted with wastewater, which contained both soluble and insoluble organic material to determine the effect of coagulation on the COD.

\subsubsection{Removal of turbidity}

Experimental results showing the reduction in turbidity achieved with the complex coagulant produced from fly ash no. PSIL are presented in Fig. 6. This figure shows that the residual turbidity of the water was reduced below $1 \mathrm{NTU}$ when a coagulant dosage of $0.04 \mathrm{mM} / \mathrm{L}$ (based on iron and aluminum) was employed under the given experimental conditions. In view of the initial turbidity of the water sample and the coagulating conditions, $0.04 \mathrm{mM} / \mathrm{L}$ can be considered as a very low dosage. However, the residual turbidity of the coagulated water increased when the dosage of complex coagulant was higher than $0.06 \mathrm{mM} / \mathrm{L}$. This may have been the result of the high concentration of residual $\mathrm{Fe}^{3+}$ in the water [11].

\subsubsection{Removal of arsenic}

The results of arsenic removal by the complex coagulant under different initial arsenic concentrations and $\mathrm{pH}$ values are shown in Figs. 7 and 8, respectively. Fig. 7 indicates that the coagulant is efficient in removing arsenic(V) from water. The arsenic removal efficiency shown in Fig. 7 was up to 97\%. Fig. 7 also shows that the arsenic removal efficiency of the complex coagulant was minimally affected by the initial arsenic concentration. Fig. 8 indicates that the $\mathrm{pH}$ of water sample had a larger effect on arsenic removal by the complex coagulant in the $\mathrm{pH}$ range of 7.2-8.6 than in the range of 5.3-7.2. This can be explained by the higher concentration of aluminum in the complex coagulant than of iron and earlier observations that the ability of aluminum to remove arsenic decreases with an increase in water $\mathrm{pH}$ [19]. In the $\mathrm{pH}$ range of

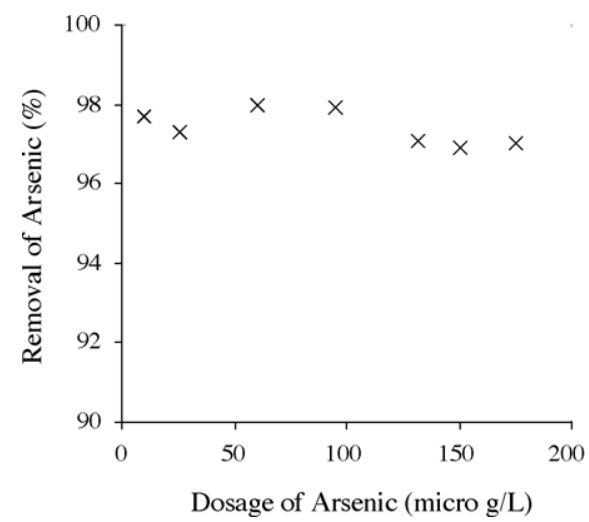

Fig. 7. Evaluation of complex coagulant produced from fly ash in removing arsenic(V) (dosage of complex coagulant $=0.1 \mathrm{mM} / \mathrm{L}$ (mole ratio of iron to aluminum $=0.62$ ), initial turbidity $=10 \mathrm{NTU}$, initial alkalinity as $\mathrm{CaCO}_{3}=37 \mathrm{mg} / \mathrm{L} ; \mathrm{pH} 7.4$ and temperature $=23.5^{\circ} \mathrm{C}$ ).

5.3-7.2, the greater ability of iron to remove arsenic probably compensated for the negative effect of $\mathrm{pH}$ on arsenic removal by aluminum. However, the compensating effect of iron was not enough to counterbalance the adverse effect of $\mathrm{pH}$ on the ability of aluminum to remove arsenic in the $\mathrm{pH}$ range of 7.2-8.6.

\subsubsection{Reduction of $C O D$}

The results of COD coagulation tests to reduce the COD of the given water sample are shown in Fig. 9. This figure indicates that the maximum COD reduction achieved with the complex coagulant was about $47 \%$. This value was determined by the characteristics of ADM water sample. About $65 \%$ of the total COD was due to the presence of soluble material. Coagulation is only effective in reducing COD due to insoluble material [14]. Therefore, further reduction of total COD in the given water sample would require using a biological process.

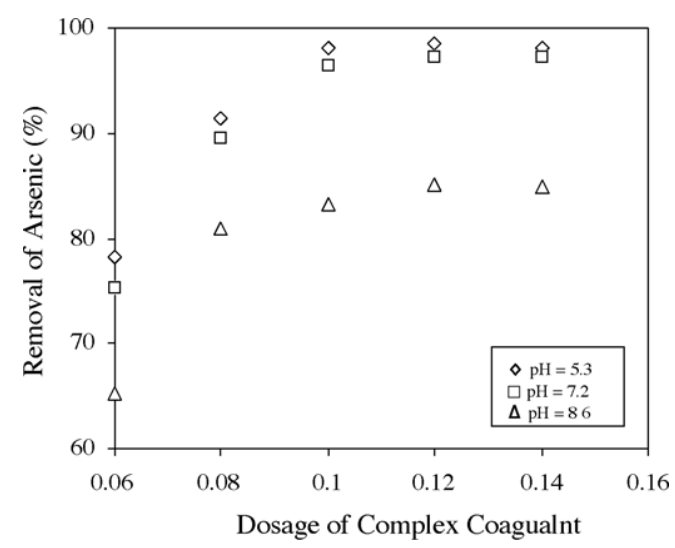

Fig. 8. Evaluation of complex coagulant produced from fly ash for removing arsenic $(\mathrm{V})$ (dosage of complex coagulant $=0.1 \mathrm{mM} / \mathrm{L}$ (mole ratio of iron to aluminum $=0.62)$, initial $\mathrm{As}(\mathrm{V})$ concentration $=100 \mu \mathrm{g} / \mathrm{L}$, initial alkalinity as $\mathrm{CaCO}_{3}=37 \mathrm{mg} / \mathrm{L}$ and temperature $=23.2^{\circ} \mathrm{C}$ ). 


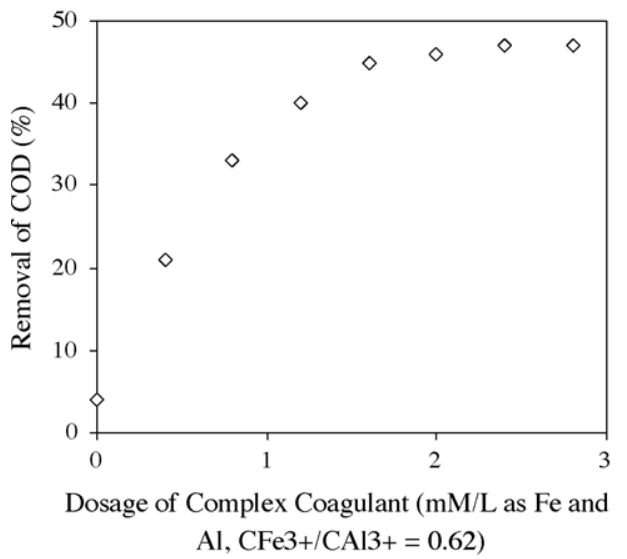

Fig. 9. Evaluation of complex coagulant produced from fly ash in reducing $\mathrm{COD}($ initial $\mathrm{COD}=1250 \mathrm{mg} / \mathrm{L}$, total suspended solids $=50 \mathrm{mg} / \mathrm{L}$, initial $\mathrm{pH}$ 8.4 and temperature $=24.1^{\circ} \mathrm{C}$ ).

\section{Conclusions}

The inorganic material in the as-received fly ash was largely in the form of spherical particles while the organic material was largely in the form of irregular particles. Most fly ash contains a large quantity of iron and aluminum oxides, two major materials used for the production of water treatment agents. One of the fly ash samples collected for this research was successfully used for the production of a sulfate-based complex coagulant by reacting the iron and aluminum oxides in the sample with sulfuric acid. The concentrations of $\mathrm{Fe}^{3+}$ and $\mathrm{Al}^{3+}$ in the complex coagulant and the conversion efficiencies for iron and aluminum oxides in fly ash are strongly affected by reaction temperature and time. The sulfate-based complex coagulant was very effective in reducing the turbidity, arsenic concentration and COD of a given wastewater sample.

\section{Acknowledgements}

We appreciate the assistance of Mr. Mark Coppler, Dr. Bob Novack, Mr. Jeff Winter, and Mr. Dennis Hungerman at Ametek Corporation and Bob Littmann at Water Inc. in supplying many of the fly ash samples. We thank Dr. Robert S Houk, Dr. Warren E. Straszheim and Ms. Stacy Scott at Iowa State University for their work analyzing fly ash samples and producing the complex coagulant. We also thank Research Institute of Innovative Technology (RITE) for Earth in Japan and US Department of Energy for their financial supports.

\section{References}

[1] D.G. Grubb, M.S. Guimaraes, R. Valencia, Phosphate immobilization using an acidic type F fly ash, J. Hazard. Mater. 76 (2000) $217-$ 236.

[2] G.J. McCarthy, J.K. Solem, O.E. Manz, D.J. Hassett, Use of a database of chemical, mineralogical and physical properties of North American fly ash to study the nature of fly ash and its utilization as a mineral admixture in concrete, Mater. Res. Soc. Symp. Proc. 178 (1990) 3-33.

[3] M. Fan, R.C. Brown, Precision and accuracy of photoacoustic measurements of unburned carbon in fly ash, Fuel 80 (11) (2001) 1414-1417.

[4] M. Fan, R.C. Brown, Modification of the loss-on-ignition technique to measure unburned carbon in fly ash, Energy Fuels 15 (6) (2001) $1545-1554$.

[5] G.M. Mudd, J. Kodikara, Field studies of the leachability of aged brown coal ash, J. Hazard. Mater. 76 (2000) 1-34.

[6] S. Horiuchi, M. Kawaguchi, K. Yasuhara, Effective use of fly ash slurry as fill material, J. Hazard. Mater. 76 (2000) 301337.

[7] M. Fan, Factors affecting the precision and accuracy of photoacoustic measurements of unburned carbon in fly ash, Ph.D Thesis, Iowa State University, Ames, Iowa, 2000.

[8] M. Fan, R.C. Brown, C.P. Huang, Preliminary studies of arsenic(III) oxidation by potassium ferrate, Int. J. Environ. Pollut. 18 (1) (2002) 91-96.

[9] M. Fan, S. Sung, R.C. Brown, T.D. Wheelock, F.C. Laabs, Synthesis, characterization and coagulation performance of polymeric ferric sulfate, J. Environ. Eng. 128 (6) (2002) 483-490.

[10] B.A. Dempsey, Polymeric aluminum chloride and alum coagulation of clay-fulvic acid suspensions, J. Am. Water Works Assoc. 76 (4) (1984) 141-150.

[11] C. Yao, The preparation of polymeric aluminum chloride and its application in water treatment. Ph.D thesis, John Hopkins Univ., Baltimore, MD, 1987, 198 pp.

[12] Peking University, Peking University's Analytical Chemistry Experiment Manual, Beijing, China, 1993, pp. 182-185.

[13] Chinese Agency of Standards (CAS), Aluminum Sulfate Quality Standard, GB 3151-82, Beijing, China, 1993.

[14] J.V. Leeuwen, Z. Hu, T. Yi, A.L. Pometto III, Use of microfungi for single cell protein production during food processing wastewater treatment, in: Water Environmental Federation's 75th Annual Conference and Exhibition, Chicago, IL, 2002, pp. 9/28-10/2.

[15] American Public Health Association, American Water Work Association, Water Environment Federation, Standard Methods for the Examination of Water and Wastewater, 16th ed., Alexandria, VA, USA, 1985.

[16] G. Parravano, J.J. Martin, D.L. Katz, Elements of Chemical Reaction Engineering, third ed., Prentice Hall PTR, NJ, 2000.

[17] O. Levenspiel, The Chemical Reactor Omnibook, Oregon State University Book Stores, Corvallis, 1996.

[18] Y. Li, Polymeric Aluminum Sulfate, Chinese Publishing House of Manufacture and Construction, Beijing, China, 1981, pp. 15-18.

[19] R.C. Cheng, S. Liang, H. Wang, M.D. Beuhler, Enhanced coagulation for arsenic removal, J. Am. Water Works Assoc. 86 (6) (1994) $79-90$. 